AC 2011-1802: TRANS-DISCIPLINARY DESIGN TEACHING FOR CIVIL ENGINEERS AND ARCHITECTS LESSONS LEARNED AND FUTURE PLANS

Sinead MacNamara, Syracuse University

(C)American Society for Engineering Education, 2011 


\section{Trans-Disciplinary Design TeACHING FOR CiVIL EngINEERS AND ArChitects - Lessons Learned and Future Plans}

\section{Introduction}

This paper describes ongoing efforts at Syracuse University to institute a trans-disciplinary course that brings together architecture and structural engineering students for a joint design seminar. This course forms part of a larger NSF funded project aimed at increasing innovation and creativity in engineering curricula. The principal aim of the overall project is to find strategies to foster and reward creativity in engineering students. The principal aim of the transdisciplinary course under discussion here is to investigate the degree to which the integration of architecture and engineering pedagogy is successful in producing desirable outcomes for either group of students. Given their different but potentially complementary skill sets, engineering and architecture students are a natural fit for investigations into creative pedagogy. In fact, the practices of both disciplines are intimately related and, yet, students whose careers may be so closely linked, rarely have opportunities for cross-disciplinary interaction in their formative years, least of all in design contexts where dialogue and collaboration could be so productive for both. This paper describes the course, the results of the evaluation of the first iteration, and ways that the course will evolve for future years. The evaluation is particularly concerned with establishing how or if this approach can change engineering students attitudes regarding creativity in engineering. We further hope to posit pedagogical strategies for successfully combining these two different student groups. Particular attention is required in the areas of division of labor in the design process and establishing a common vocabulary to successfully articulate and appreciate design goals in both disciplines.

\section{Background}

The pedagogies of the two disciplines are not obviously aligned. The common engineering teaching paradigm divides complex problems into many pieces which students are then taught to solve independently, all the while anticipating that eventually, they will "be able to develop a solution by combining them...Eventually...the effort involved in learning about the small pieces is so overwhelming that we can longer synthesize the original problem-the parts become more important than the whole." Further, the engineering curricular focus on solving "one problem at a time," assuming a singular answer or solution, stands in direct contrast to "the history of modern technology and society in all its vital messy complexity."2 As Charles Vest, former President of MIT writes, "There are two frontiers of engineering" and "each is associated with increasing complexity." By comparison, the discipline of architecture's curriculum and pedagogy consciously and actively fosters and rewards creativity. Architecture students prioritize innovation and continuously engage in creative thinking while keeping an eye on the big picture: the cultural significance and ultimate aims of the "program" in relationship to the cultural and environmental context of the project. Students are exposed to the best examples of creative endeavor and cutting-edge design practice and taught the history of their field. Throughout their education, students are exposed to a range of approaches and methodologies for problem-solving design, helping to provide the understanding the no one approach is paramount. Architecture students however, lack the technical skills and expertise of their engineering peers because they take very few hard science, math, or engineering courses. It is usually only through professional 
experience over many years that architects gain the technical expertise to be able to effectively communicate with their engineering collaborators.

Engineering education researchers and practitioners have widely acknowledged the problem of design education in engineering programs. Previous studies of engineering student design processes report a significant difference between the capacity of student engineers and engineering practitioners in "problem scoping" and "information gathering" at the start of a design project, and argue that engineering students would benefit from teaching methods designed to model that process for them. ${ }^{4}$ In the 1990s first-year design courses were widely introduced in engineering programs in an attempt to introduce students to the nature of their chosen profession earlier in their college careers. ${ }^{5}$ Dym et al identify a host of institutions (Harvey Mudd, Purdue, Northwestern, Penn State, Colorado School of the Mines, University of Alabama, Columbia, Cooper Union, Drexel, NJIT, Ohio State, Polytechnic South Carolina, USC, Carnegie Mellon, University of Colorado at Boulder, Georgia Tech) that introduced design thinking through project-based learning in their first year programs. ${ }^{6}$ Most of these schools reported a positive impact on retention for those students who had taken some form of first year "cornerstone" engineering design course. Dym et al further argue that such courses have a positive impact on student interest and performance in later engineering courses. Capstone design courses at the end of engineering programs likewise represent an opportunity for students to take both design work and a whole real world structure.

Katehi has described "creative experiential, problem based learning" as the model for future engineering curricula if the US is to maintain a technologically and economically competitive workforce. ${ }^{7}$ Teaching engineering design as a vehicle to incorporate creativity into engineering curricula is widely acknowledged by engineering education researchers ${ }^{8}$. Blicblau and Steiner, describing the role of final year engineering projects at the Swinburne University of Technology in Melbourne Australia, argue that engineering students have difficulty integrating their studies into real engineering situations because of lack of exposure. It is this capacity to integrate knowledge and skills into the practice of engineering that creates the creative engineer. They found that using real world projects strengthened student understanding and engendered a more creative approach to problem solving. ${ }^{9}$ Court found that while some students are well adapted to finding radical solutions to problems others are more skilled at improving on existing models, and argues that design teaching must find ways for students to contribute to design these different ways and to reward both approaches. He further argues that group work in particular multidisciplinary work is particularly advantageous in pursuit of creativity in engineering design education, and that the only way to develop creative design skills is in coaching in practical design $^{10}$. Katehi also argues that the boundaries between disciplines have proven limiting to creative problem solving. ${ }^{11}$ Acar, discussing an interdisciplinary systems course in an MEng degree at Loughborough University in the UK, further highlights the importance of interdisciplinary education in the face of increasing complexity in engineering practice, the value of open ended problem solving with no "one right answer", and the requirement to teach students how to access, interpret and integrate expert knowledge into their work. ${ }^{12}$

\section{The Course}

This course has been outlined in more detail in previous papers ${ }^{13}$. In brief, the trans-disciplinary 
design seminar (TDS) aims to integrate engineering research into the creative design process. This model accommodates creative and research activities such as open-ended problem solving, resolving competing goals in a complex problem, balancing technical merit against architectural design values, and positing speculative designs. For the first iteration of this initiative, 24 students, (11 engineers, 13 architects) came together for a 3 credit hour technical design seminar that is oriented towards a series of design projects that span civil engineering and architecture and is taught by a structural engineer and an architectural designer. For engineering students, the TDS was an opportunity to experience one-on-one instruction typical of design studios, or "deskcritiques" in the architecture vernacular. For architecture students this was an opportunity to work with technical constraints in a new way. The students completed almost all assignments in architect/engineer pairs. The final project was in teams of four (half architecture half engineering). The groups were mixed up for each new project. As the numbers were uneven there was the occasional architect-architect pairing (interestingly, we found this often resulted in the least interesting design work). Further when we gave the students one opportunity to pick their own partner (inside or outside their discipline), three quarters of the class chose to form an interdisciplinary team.

The course is an elective in both schools, but we hope that once the curriculum has been tested and refined that we will ultimately apply what we have learned to capstone design in engineering and design studio in architecture. By quirk of scheduling and other core requirements all of the engineering students in the course so far have been third year students. These students are all in the civil and environmental engineering program and most have a primary interest in structural engineering although some are concentrating in geo-technology or water resources. No GPA requirement was imposed to join the course, although we have found (with a few exceptions) that the engineering students who take the initiative to sign up for this course are those with higher GPAs. The engineering students at this stage have all taken, Statics (with the author), Mechanics of Solids, Structural Analysis, and most are taking Concrete Design simultaneously. The architecture students taking the course range from second year to graduate students. They are required to take two structures courses, and a series of building technology courses that expose them to structural systems alongside other building systems. The differing backgrounds of the architecture students has not proved to be the obstacle that it might have done, and we suspect that the subject matter (Shell Structures) which is relatively new to all of them explains this phenomenon. In both years of the course we have had a gender balance equivalent to that of the College of Engineering and the School of Architecture in the course (the CoE has $35 \%$ female students, the SoA approximately 50\%).

The subject matter for this first iteration of the TDS was Shell Structures. This was chosen because: it fit the faculty expertise at hand, curvilinear form is prominent in contemporary architecture, and we posited that a non-normative form would prevent preconceptions that might stymie creativity for both groups of students. The students undertook a series of short design exercises in the first to thirds of the semester: paper models investigating parabolic form; funicular fabric models using water (and the reliable Syracuse winter) to create frozen shells in perfect compression; a study on modules and their aggregation (using milling and vacuum forming technologies); and precedent analysis where each group reviewed the technical and architectural literature on an assigned structure and made a presentation. The final design project was to redesign the Regional Transportation Center in Syracuse using a shell structure to 
incorporate the bus and train station. Students performed a FEM analysis of their proposed shell as part of the design process, and were required to present the both the technical and architectural rationale for their design to final jury of architects and engineers. Examples of some of the models and images produced are shown in Figures 1-4.
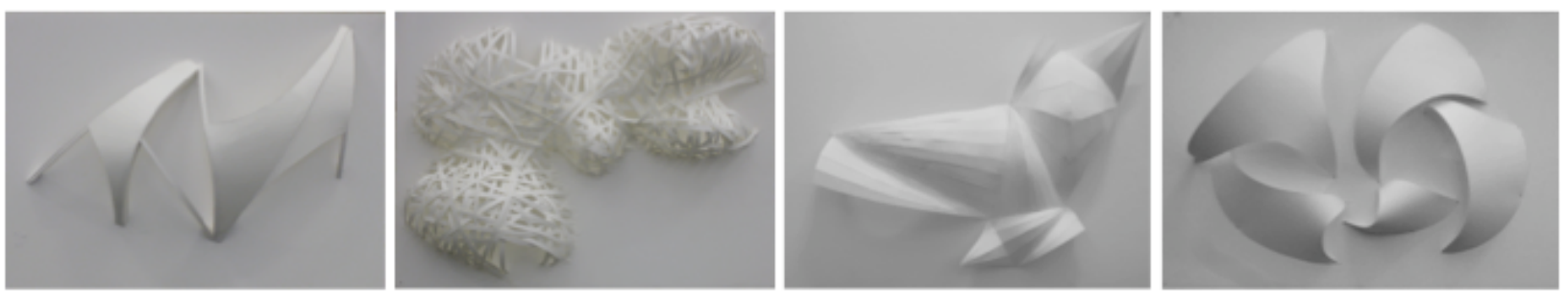

FIGURE 1

PAPER PARABOLAS
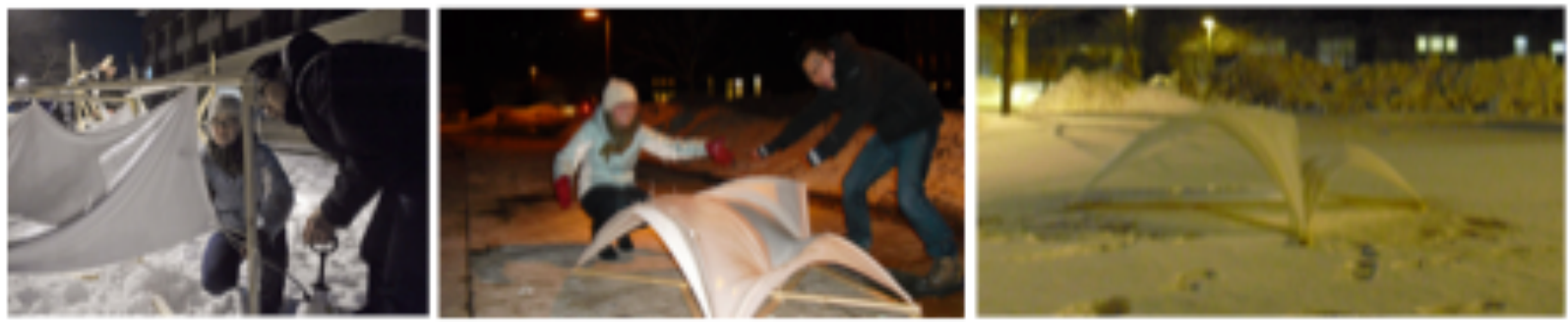

FIGURE 2

FROZEN FORM
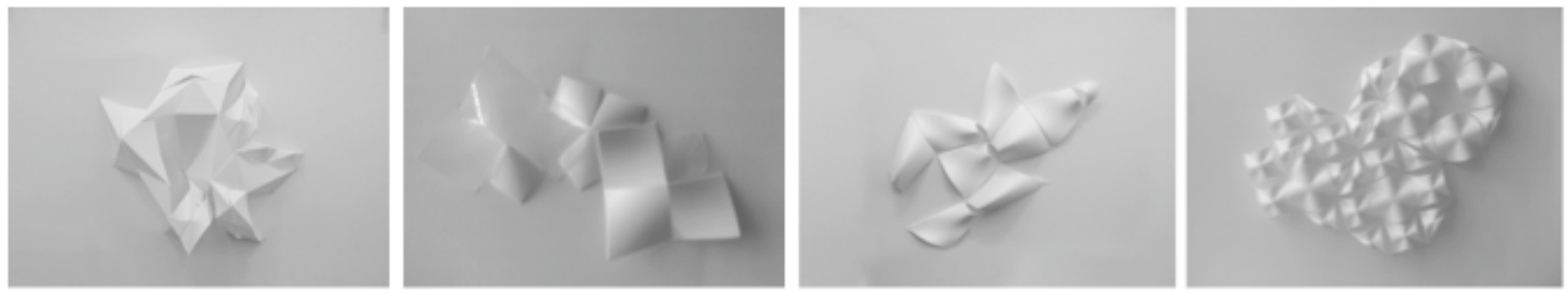

FIGURE 3

AgGregation AND APERTURE
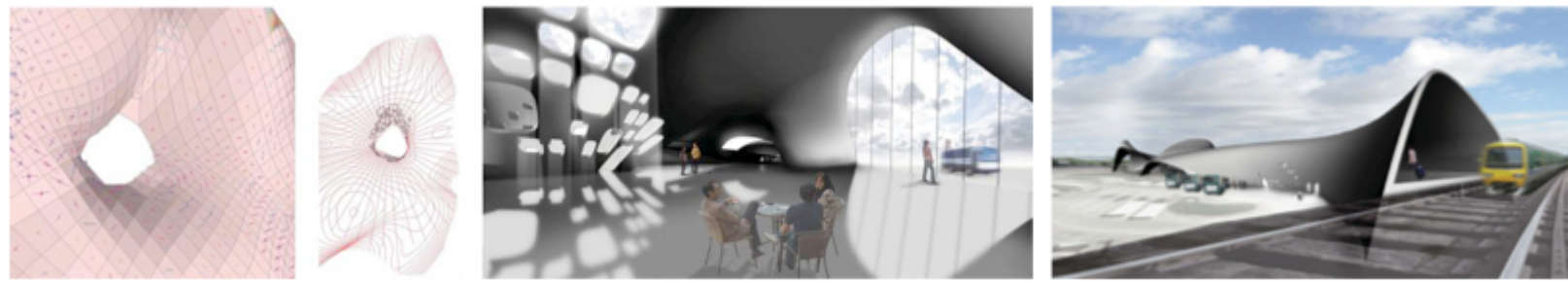

FIGURE 4

FinAL DESIGN - STUDENTS USED FEM ANALYSIS OF STRESS PATHS TO PLACE WINDOWS 


\section{The Evaluation Plan}

The evaluation of this course will be vital to both further refinement of its curriculum and to the potential dissemination of the teaching model. The Office of Professional Research and Development in the School of Education at Syracuse University is conducting the evaluation of the project. The first year evaluation plan included a written materials review, pre and post surveys, tests, interviews, and classroom observations. Students were surveyed at the start of the semester about their expectations of the course; their perceptions of their own discipline as related to a variety of attributes (including creativity, logic, ability to solve complex problems, etc.); their perceptions of themselves as related to the same attributes; and their crossprofessional perceptions. After an initial analysis of responses, the survey was followed up with interviews for further depth. The students repeated the survey about disciplinary and crossdisciplinary perceptions after the course was over (and grades has been posted). At this time students were also asked some direct questions about whether the course changed their opinions about the opposing discipline. This paper details the findings from the first iteration of the course, both pre and post evaluation as well as observations from the teaching faculty, the visiting faculty, the evaluation team, and the student focus groups.

\section{Faculty Observations}

Both faculty members teaching the course kept a journal of activities and observations throughout the course. The most immediate and obvious difference that emerged between the two groups of students was that architecture students were much more comfortable with the entire concept of design than the engineering students and that architecture students had a much wider definition of their discipline than did the engineering students. This is not surprising, and is likely a direct result of the pedagogy models in the two disciples. Architecture courses will often draw on disparate ideas and theories form literature, politics, history, science and technology. Engineering courses are both more like one another and more narrow in their focus, as befits the attempt to convey specialized knowledge. In a pre-course survey it was also revealed that architecture students were much more familiar with the history and contemporary practice of their discipline. ${ }^{14}$

The presentation of each project (four smaller assignments and one final design project) gave an opportunity to observe the student response to the coursework. The students worked in pairs, generally one architect and one engineer. In approaching design projects (such as the first assignment - to create five differently sized volumes in one model using paper and the knowledge that parabolic forms perform well in compression) the engineering students expressed frustration at the open ended nature of the assignment, and were clearly concerned that there was no one solution that would result in the maximum grade. Ironically when presenting their models, each engineering student without being prompted explained the entry point that each had chosen into the problem (one had concentrated on rigidly controlling the area required to be covered, another had established a series of parabolic curves that when extruded or rotated made the volumes of the space). Given that engineering students are accustomed to much more tightly defined assignments, it is encouraging that they immediately recognized this difference and moved to set up the parameters of the problem themselves. As the semester progressed the engineering students became more confident in their presentations. 
Continued interaction with the students who took the course has yielded evidence that the course made a difference to their education. Three of the engineering students have expressed an interest in graduate work in architecture, architectural engineering, or engineering programs with specific focus on shells or form finding and design more generally. One of those students is also undertaking independent study on shell structures under the supervision of author. A further engineering student has undertaken an honors thesis (also under the direction of the author) that looks at the aesthetic, cultural, political influences in the structural design of tall buildings.

The final projects for the course were presented in an architecture style final pin-up. Both the teaching faculty of the course and the senior architecture and engineering faculty members invited as the jury agreed that the design work was of a high standard, and that the level of creativity was very high. The architecture jurors were particularly impressed with the engineering students' capacity to articulate their design goals, both technical and architectural.

\section{Evaluation Team Observations}

As part of the overall evaluation of the course, the evaluation team observed the final project pinup and met with the students in smaller focus groups both before and after the course. They had two significant remarks from those activities. The first was that the focus groups revealed a remarkable "buy-in" on the parts of both groups of students to both the concept of transdisciplinary teaching and to the experimental nature of the course. The students were anxious to play their part in improving the course and in ensuring that a connection between the two departments be maintained. The second observation was very surprising to the teaching faculty. On the day of the final review, during the presentations, the evaluation team in the classroom found themselves unable to identify which students were engineers and which were architects. This bodes very well for the adaptability of engineering students to alternate modes of pedagogy.

\section{Student Perceptions Study}

The primary purpose of the perceptions study was to identify the extent to which the course changed students opinions about their own discipline and the "other" discipline, and specifically to identify if the course altered engineering students' perceptions of themselves and their disciple as creative and innovative.

At the end of the course students were asked specifically if the course had altered their opinions of the "other disciple" and if they would recommend the course to their fellow students (Figure 5). The response of the engineers to the post course questions are shown in Figure 6 and the architects' responses are in Figure 7. The architecture students' responses are more definitive. The overwhelming majority of the group thinks more positively about engineering students and engineering as a disciple as a result of taking the course and all the respondents believe they had improved their engineering knowledge. For the engineering students, a small minority thinks more negatively of the discipline of architecture (although interestingly not of its students) after taking the course. However, the majority express increased positivity towards both architecture and architecture students. All engineering students agree that they now have more knowledge of 
architecture (although this author feels compelled to confess, knowledge of architecture at the start of the semester was so minimal that this was not an especially difficult pedagogical feat!). Most encouragingly, every student surveyed agreed or strongly agreed that they would recommend the course to a colleague.

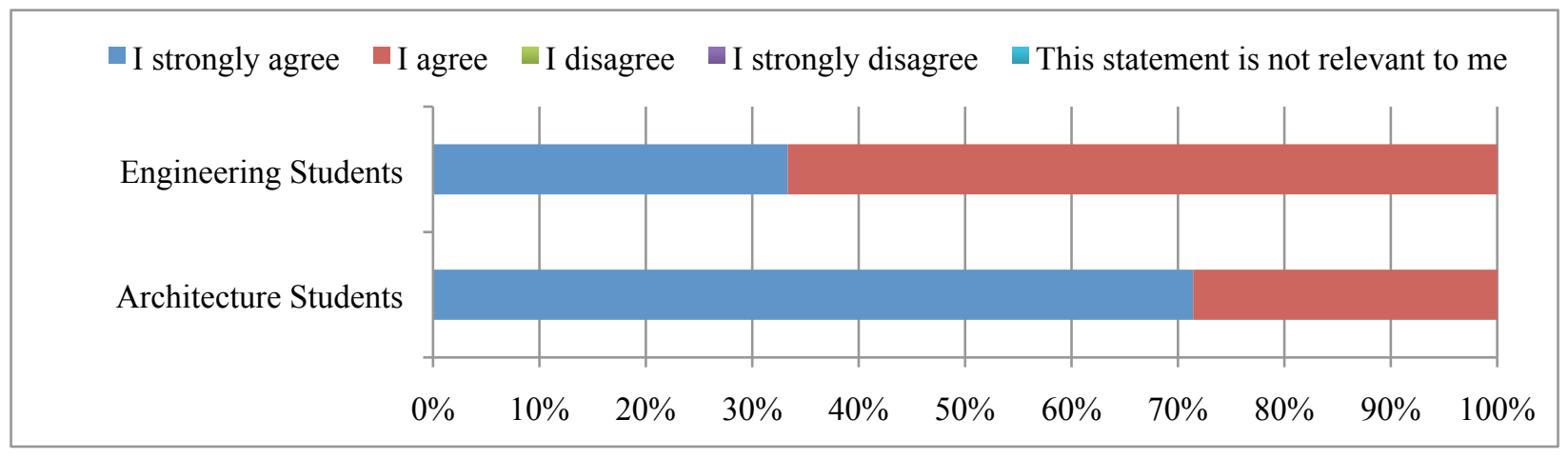

FIGURE 5

I Would Recommend This Course To My Fellow Students

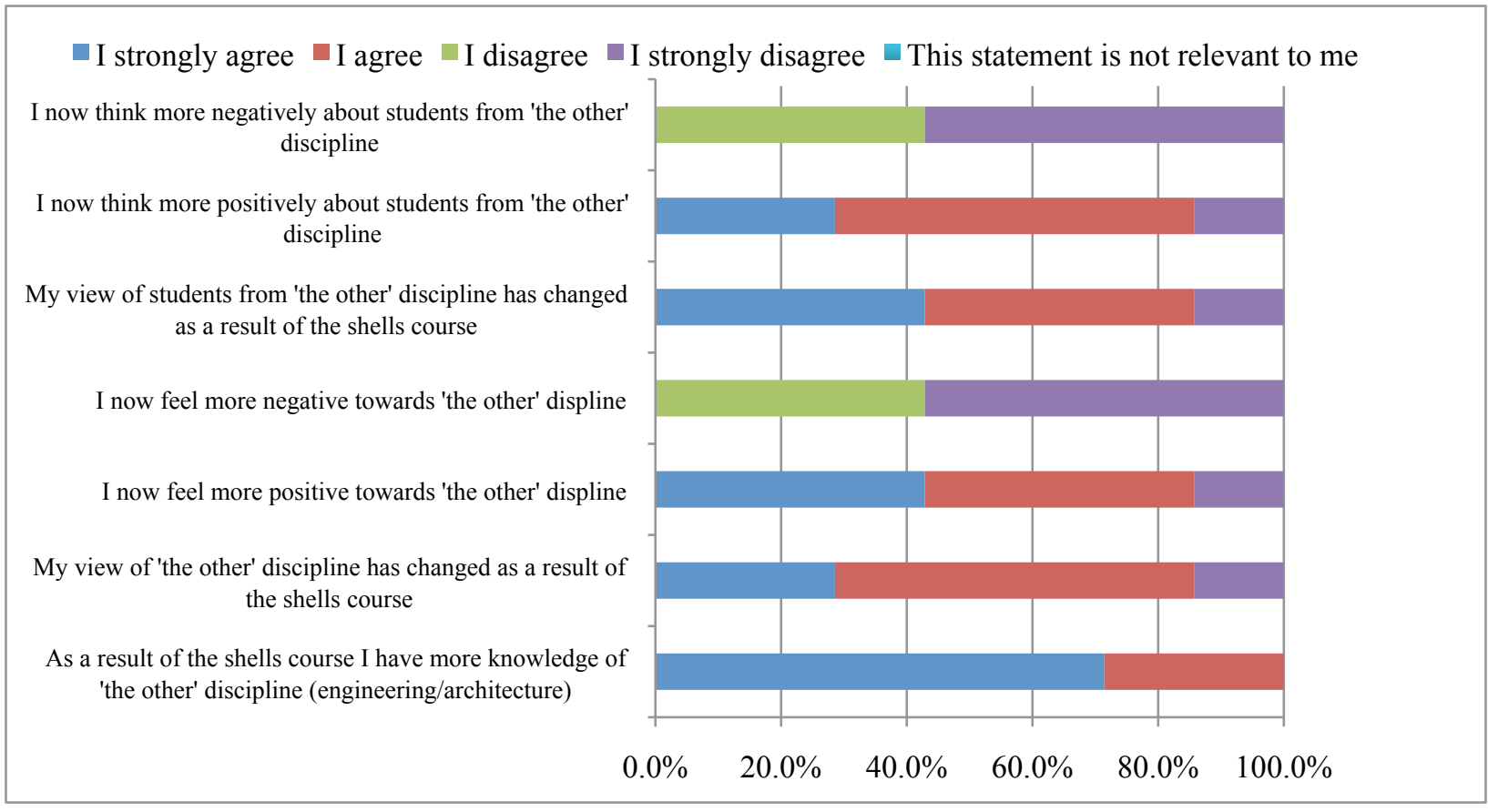

FIGURE 6

Architecture Students’ Post-Course Responses 


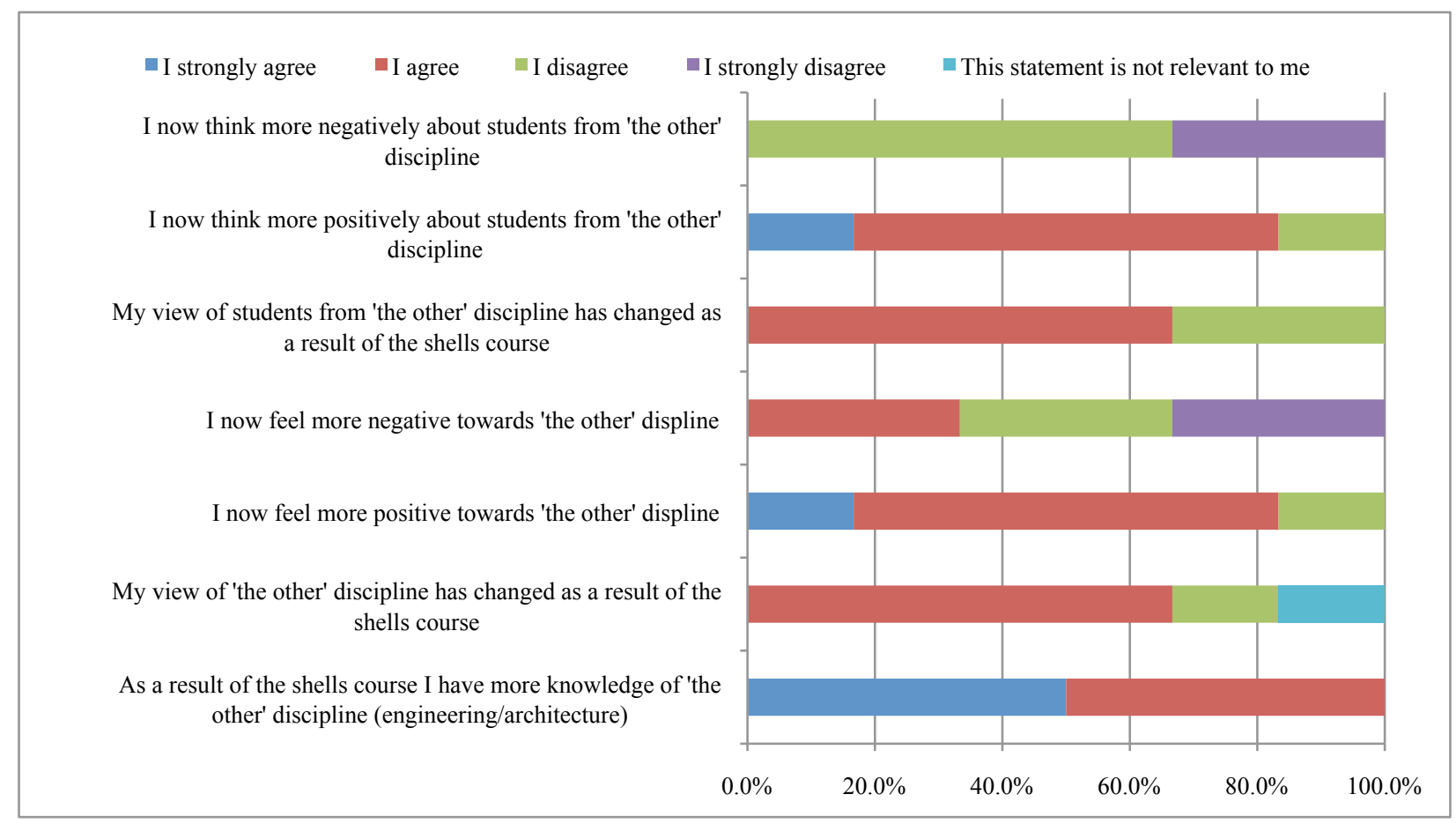

FIGURE 7

EngineERING Students' Post-Course Responses

To further investigate both pre-existing assumptions and any change that might occur students were presented with a series of attributes and asked to identify the extent to which they believed them to describe the average professional engineer or architect. They were also asked to identify the extent to which they believed the same characteristics to describe themselves. This survey was administered both before and after taking the course. Figures 8-19 contain the results of student's perceptions of themselves, their discipline and the other discipline, both before and after the course. The density of the information provided is such that they have been moved to the end of the paper and a summary of the principal findings are presented here:

\section{Architecture Students on their Profession}

- Architecture students generally rated their profession very highly.

- The characteristics architecture students most associate with their profession are intelligence, problem solving, confidence, innovation, and creativity.

- The characteristics architecture students least associate with their profession are flexibility, capacity for analysis, team-work, logic, structure, and collaboration.

- There was little change in architecture students perceptions of their profession in the post course survey. 


\section{Architecture Students on themselves}

- For all characteristics architecture were much more likely to assign "extremely" to a professional and "very" to themselves.

- When you put together the "extremely" and the "very" responses the architecture students view of themselves is much the same as their view of the profession.

- The notable exception is in technical competence. While almost $80 \%$ of the architecture students ranked professional architects as extremely or very technically competent, just over $50 \%$ of them said the same about themselves before the course.

- After taking the course and working with the engineering students their confidence improved and $85 \%$ of them rank themselves as "extremely" or "very" technically competent.

\section{Engineering Students on their Profession}

- Engineering students displayed more dissonance than the architects between their view of their chosen profession and their view of themselves.

- The characteristics engineering students were most likely to associate with their profession pre -course were: intelligence, technical competence, logic and problem solving.

- The characteristics engineering students were least likely to associate with their profession were: flexibility, diversity, multi-talented, being artistic, innovation, and creativity.

- The pre-course perceptions study was also administered to a comparisons group of 80 engineering students and very similar results were found. ${ }^{15}$

- Although the number of students in the study is small, there was a definite increase in the respondents describing engineering professionals as multi-talented and big-picture thinkers in the post course survey.

- The percentage of engineering students who would describe the engineering profession as a least moderately artistic went from less than $20 \%$ to over $80 \%$ after taking the course.

\section{Engineering Students on themselves}

- As a group the course engineering students viewed themselves as marginally more flexible and artistic, than the average engineering professional

- The engineering students rated themselves as more innovative and more creative than the average professional engineer.

- Engineering students viewed themselves as less intelligent, less technically competent, and slightly less logical than the average professional engineer.

- These views did not change significantly during the course.

In order to inform the course planning for this and future trans-disciplinary design courses, each group of students was asked to evaluate the "other" profession in terms of the same characteristics. The results for architects on engineers are in Figures 16 and 17. The results for engineers on architects are in Figures 18 and 19. The results indicate the stereotypical strengths and weaknesses each group assumes the other to have. 


\section{Architecture Students on Engineers}

- Before the start of the course the architecture students almost all rated engineers as either "extremely" or "very": intelligent, technically competent, organized, analytical, structured, logical, and able problem solvers.

- Architecture students also rated engineers highly in teamwork, collaboration, confidence, and innovation.

- Architecture students were least likely to identify engineers as flexible, artistic or creative.

- After the course they downgraded their ratings of engineers in teamwork and flexibility considerably.

- After the course architecture students were even less likely to think engineers were artistic.

- These findings are in contrast to the overall report that architecture students think more positively about engineering and engineering students when asked more general questions.

\section{Engineering Students on Architects}

- Engineering students almost all rated architects as "extremely" or "very" artistic, innovative, and creative.

- Engineering students rated architects highly as intelligent and confident.

- Engineering students did not consider architects as analytical, logical and able problem solvers before taking the course.

- After the course the biggest change was that they ranked architects as much higher in problem solving and logic.

- These findings support the findings from the more general questions that engineers thought more positively about architecture students after taking the course.

There are also differences between the way each profession views the other versus how they view themselves. Architects rated their profession much higher in terms of problem solving, technical competence, logic and capacity for analysis, than did the engineers. Engineers rated their profession as more creative, more flexible, marginally more artistic and better at big-picture thinking than did the architects.

\section{Future Plans}

The basic framework of the class delivery (i.e lectures interspersed with lab sessions for specific skills, design working sessions, and critique sessions) will be unchanged. The basic framework of the course assignments (three of the four initial assignments) will stay the same, and the final assignment will be of the same scope and topic. One design assignment will be transformed into a group design faculty-led, 4-hour design charrette. This change is proposed because this assignment was the least successful last year and in response to the evaluation team's observation that engineering students initially felt left out of the design and planning aspects of 
the projects. This will be a good opportunity for faculty: to model design thinking for engineering students, to observe how the students work together, to encourage the engineering students to assert themselves. The schedule of the course will be rearranged to give an extra week of working time for the final project. This is in response to comments from both groups of students that this last project felt rushed. A longer time frame for the final work will also allow for multiple pin-ups to reinforce the iterative nature of both engineering and architectural design. It will allow for more explicit integration of the structural analysis results into the final designs, to further clarify the engineering students' role in the design process. The final project review jury will be made up of half engineering, half architecture experts. An outside engineer (in practice or a faculty member from outside the University) will be invited to at least one pin-up during the semester. As with last year in-house engineers will continue to be invited to pin-ups as available. These changes are in response to student comments in the post course focus groups that work was judged largely by architecture standards. An undergraduate student TA has been engaged for the course. She is an engineering student who took the TDS course last year. We believe that seeing a peer engineer with design interests and expertise will be a positive motivation for the engineering students. To capitalize on the good "buy-in" to the experimental nature of the course last year, we will invite some previous students (architecture and engineering) to take part as critics at the first pin-up. We have invited a guest lecturer from Buro Happold (a prominent engineering company known for innovate work with architects) to give a talk about that firm's work in shells. These changes are largely aimed at improving outcomes for the engineering students in the course.

\section{Conclusions}

The course is a work in progress and the results of the first semester are encouraging. Student enthusiasm for the course is high for both groups. The quality of the design work was highly rated by both the teaching faculty and the final project jury. Several individual students have ongoing engagement with academic issues they first encountered in the course. Each group of students had generally improved opinions of the other after taking the course. The biggest changes in student disciplinary perceptions where that architects gained technical confidence after taking the course and engineers viewed their profession as more multi-talented, big-picture thinking and considerably more artistic. As the course evolves the primary aims will be to engage the engineering students more deeply in the design process and improve their confidence in creativity and innovation in both their own work and in the wider discipline. 


\begin{tabular}{|c|c|c|c|c|c|}
\hline $0 \%$ & $\begin{array}{r}\text { Extremely } \\
20 \%\end{array}$ & $\begin{array}{l}\text { Very } \\
40 \%\end{array}$ & $\begin{array}{c}\text { Moderately } \\
60 \%\end{array}$ & $\begin{array}{l}\text { Slightly } \\
80 \%\end{array}$ & $\begin{array}{l}\text { Not at all } \\
100 \%\end{array}$ \\
\hline & & & & & $\begin{array}{l}\text { Intelligent } \\
\text { Flexible } \\
\text { Technically } \\
\text { Diverse } \\
\text { "Big picture" } \\
\text { Multi-talented } \\
\text { Organized } \\
\text { Intuitive } \\
\text { Analytical } \\
\text { Team-workers } \\
\text { Artistic } \\
\text { Structured } \\
\text { Logical } \\
\text { Collaborative } \\
\text { Able problem- } \\
\text { Confident } \\
\text { Innovative } \\
\text { Creative }\end{array}$ \\
\hline
\end{tabular}

FIGURE 8

Architecture Students on Architects Pre-Course

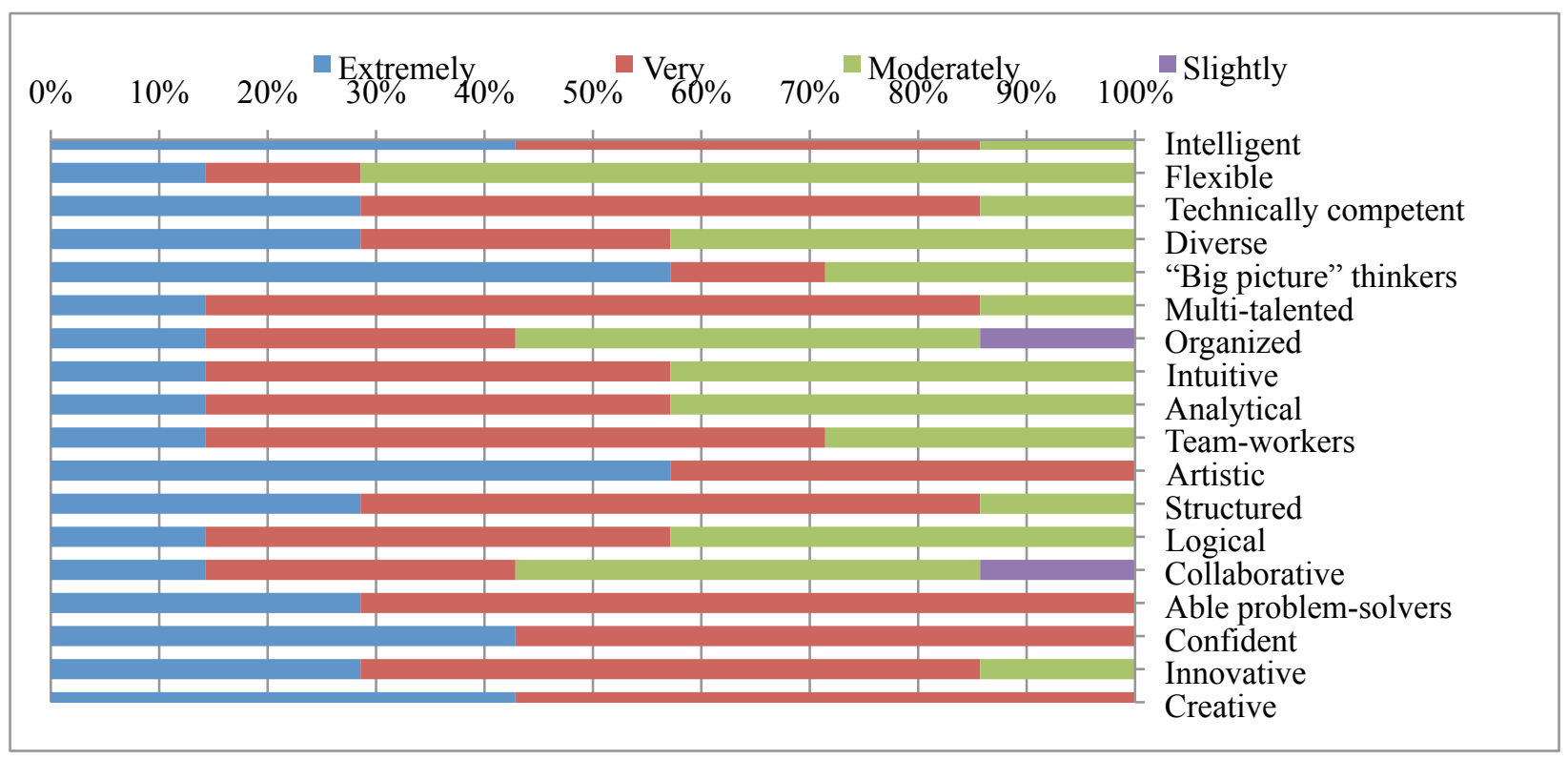

FIGURE 9

Architecture Students on Architects Post-COURSE 


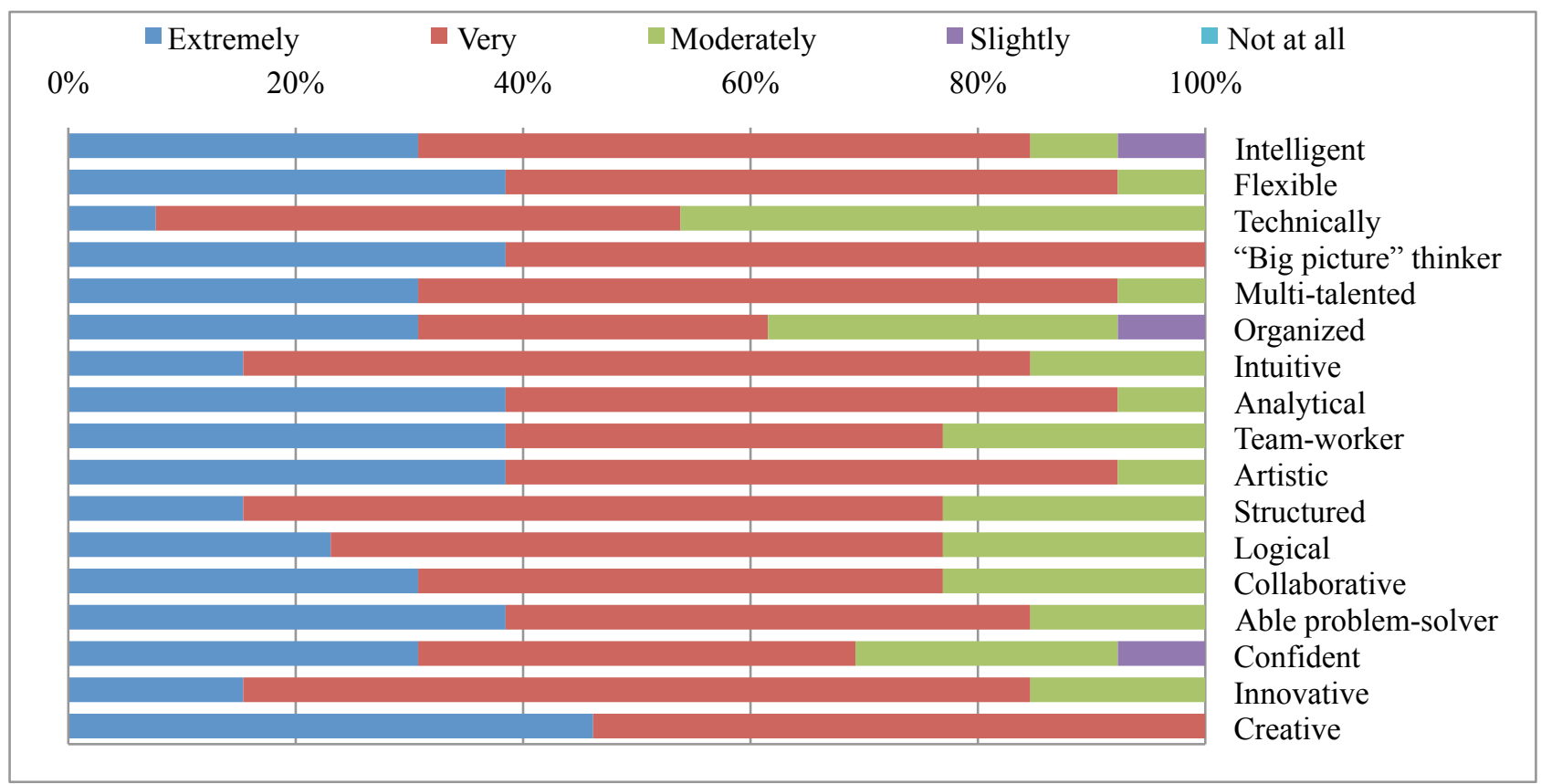

FIGURE 10

Architecture Students on Self Pre-Course

\begin{tabular}{|c|c|c|c|c|c|c|c|c|c|c|}
\hline \multirow[b]{2}{*}{$0 \%$} & \multicolumn{2}{|c|}{ Extremely } & \multicolumn{2}{|c|}{ Very } & \multicolumn{3}{|c|}{ Moderately } & \multicolumn{2}{|c|}{ - Slightly } & \multirow[b]{2}{*}{$100 \%$} \\
\hline & $10 \%$ & $20 \%$ & $30 \%$ & $40 \%$ & $50 \%$ & $60 \%$ & $70 \%$ & $80 \%$ & $90 \%$ & \\
\hline & & & & & & & & & & Intelligent \\
\hline & & & & & & & & & & Flexible \\
\hline & & & & & & & & & & Technically competent \\
\hline & & & & & & & & & & "Big picture" thinker \\
\hline & & & & & & & & & & Multi-talented \\
\hline & & & & & & & & & & Organized \\
\hline & & & & & & & & & & Intuitive \\
\hline & & & & & & & & & & Analytical \\
\hline & & & & & & & & & & Team-worker \\
\hline & & & & & & & & & & Artistic \\
\hline & & & & & & & & & & Structured \\
\hline & & & & & & & & & & Logical \\
\hline & & & & & & & & & & Collaborative \\
\hline & & & & & & & & & & Able problem-solver \\
\hline & & & & & & & & & & Confident \\
\hline & U & & & & & & & & & Innovative \\
\hline & T & & & & & & & & & Creative \\
\hline
\end{tabular}

FIGURE 11

Architecture Students on Self Post-Course 


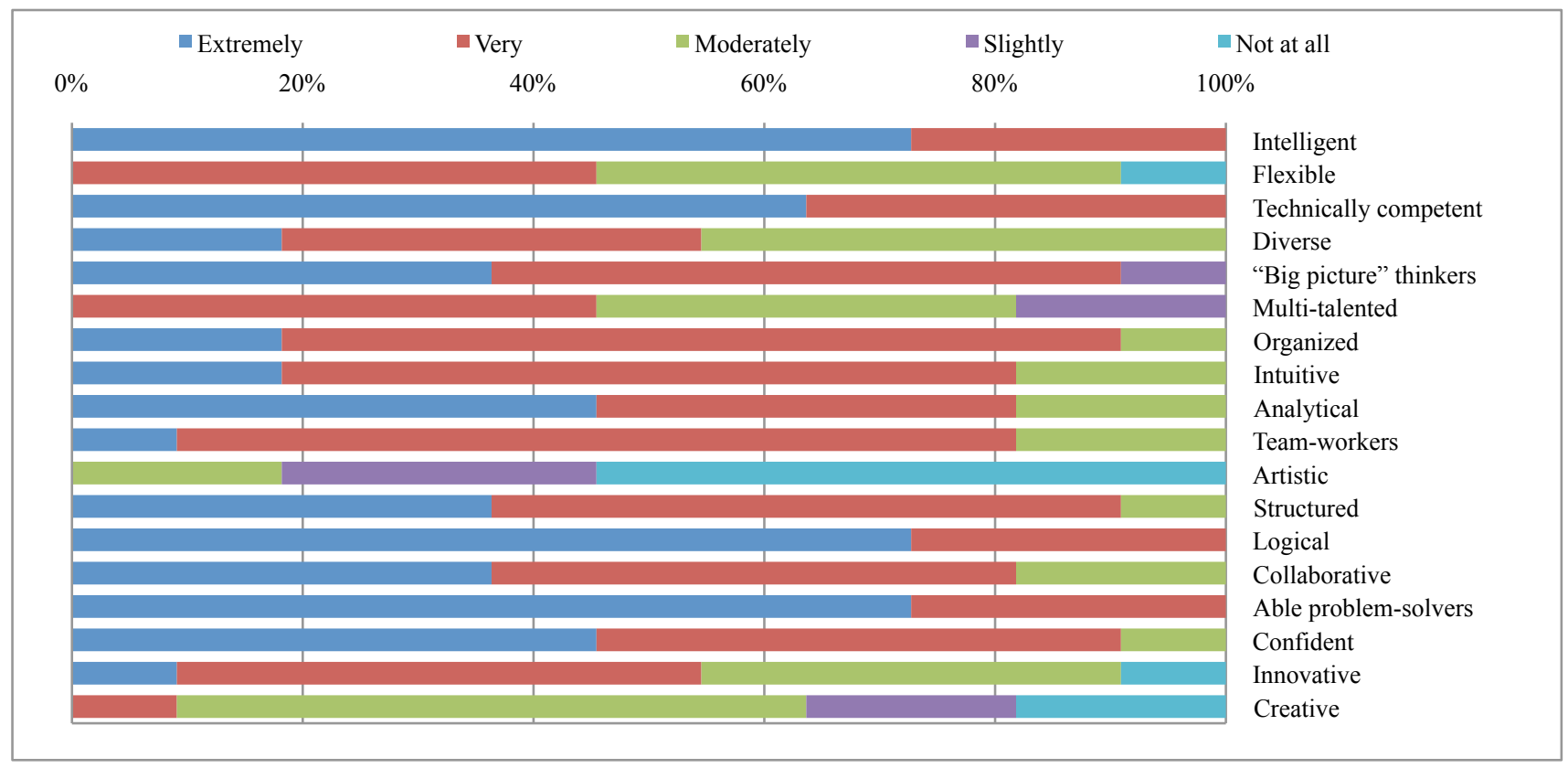

FIGURE 12

ENGINEERING Students ON ENGINEERs PRE-COURSE

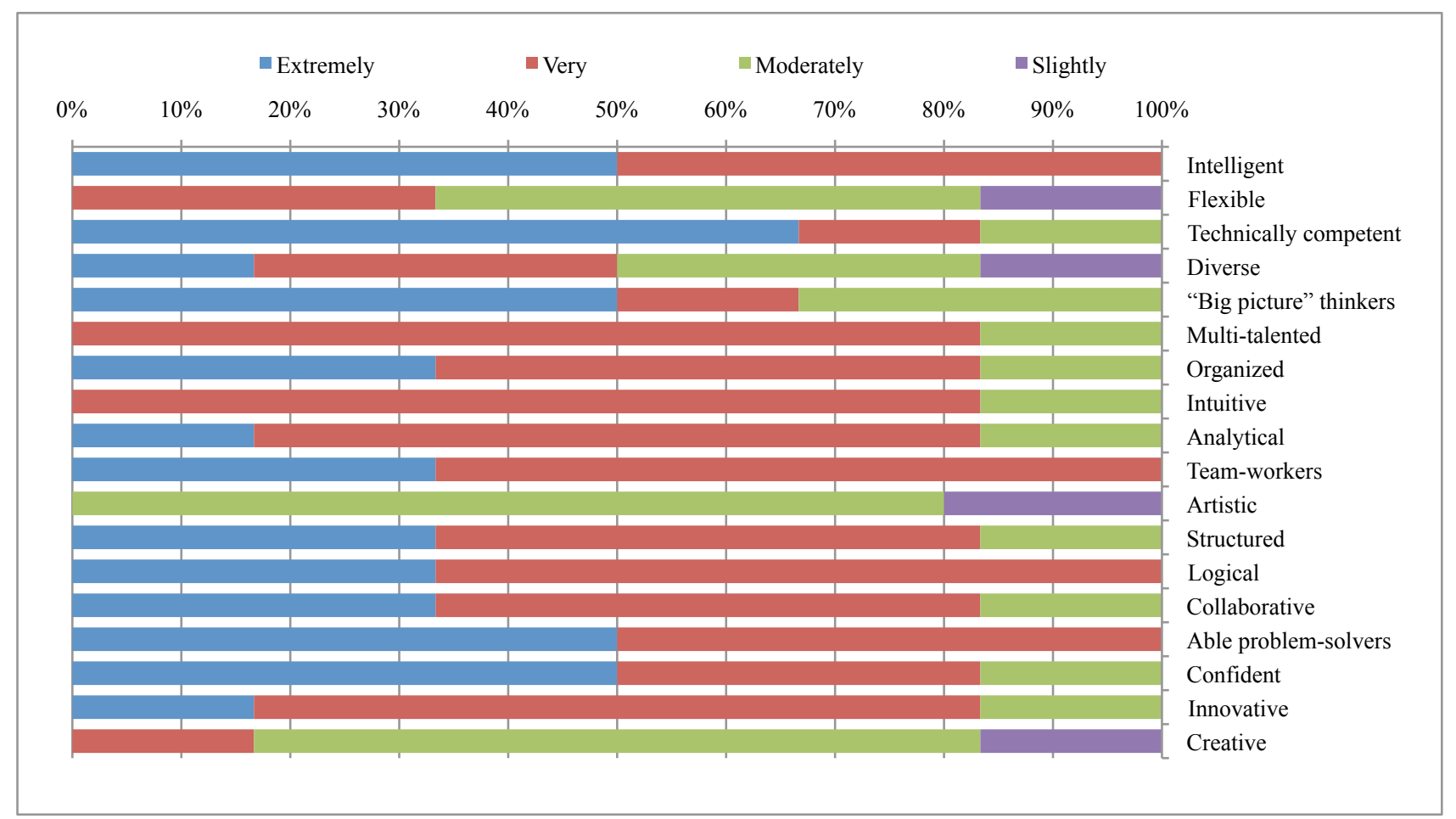

FIGURE 13

EngineERIng Students on Engineers Post-Course 


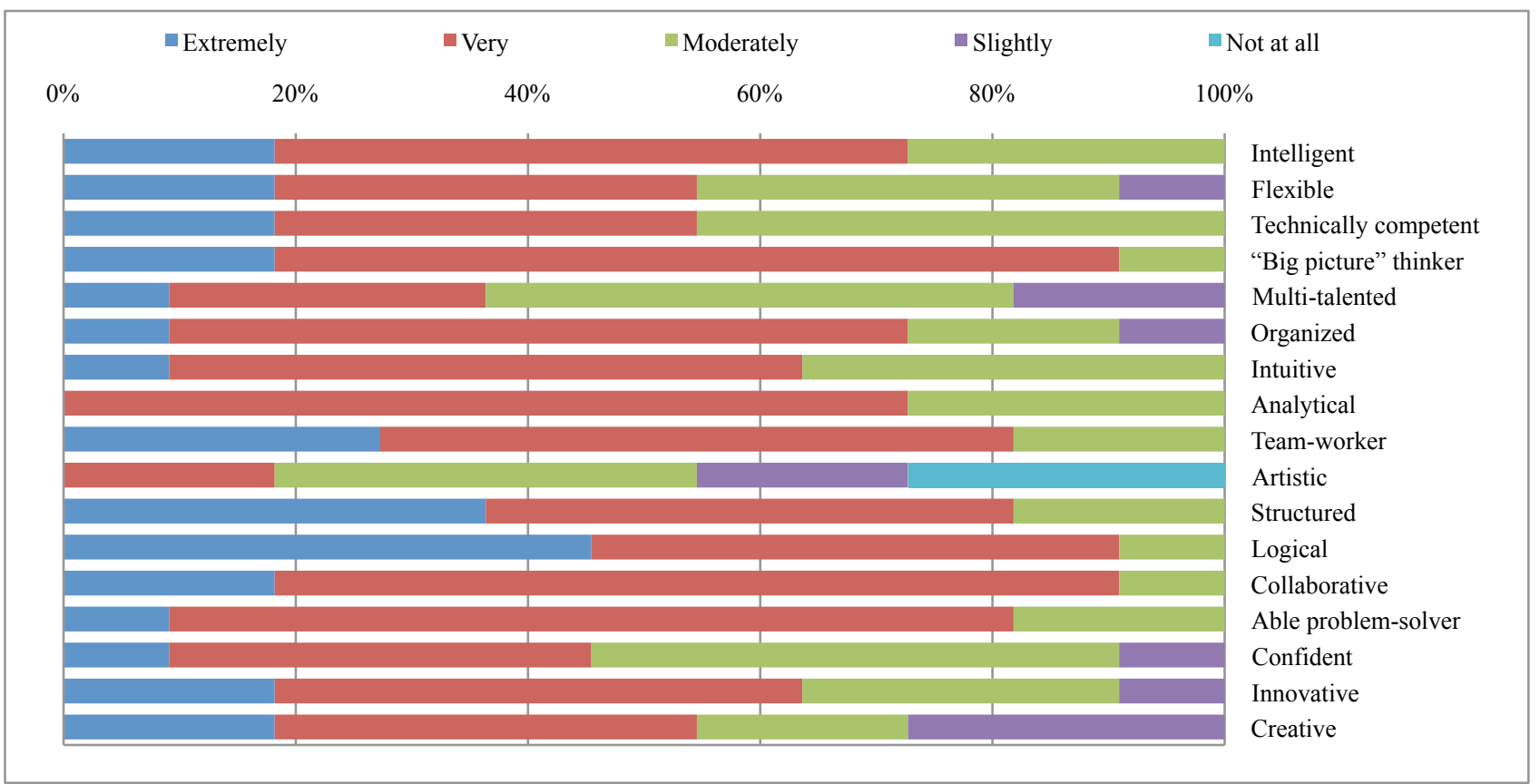

FIGURE 14

Engineering Students on Self Pre-Course

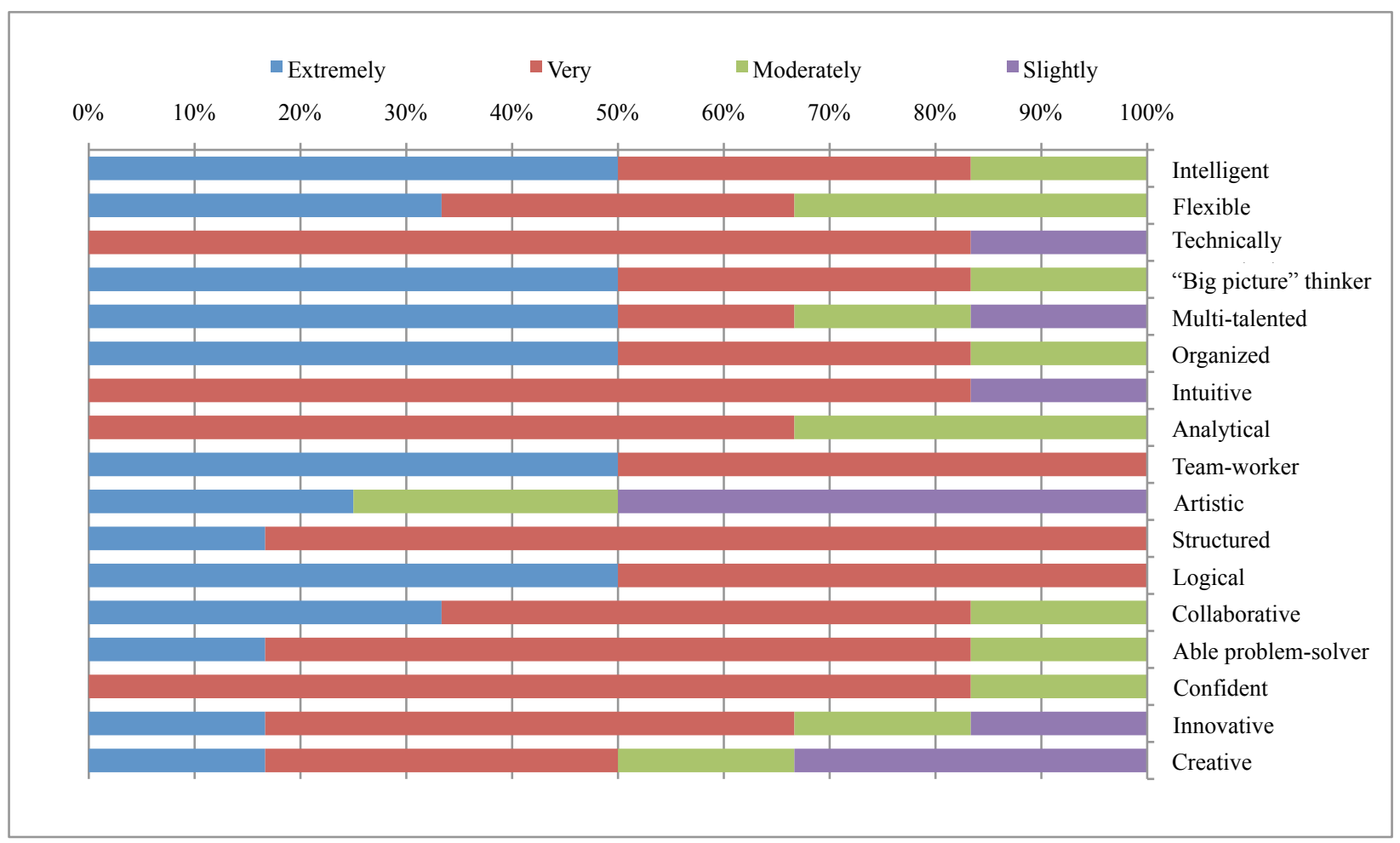

FIGURE 15

Engineering Students on Self Post-Course 


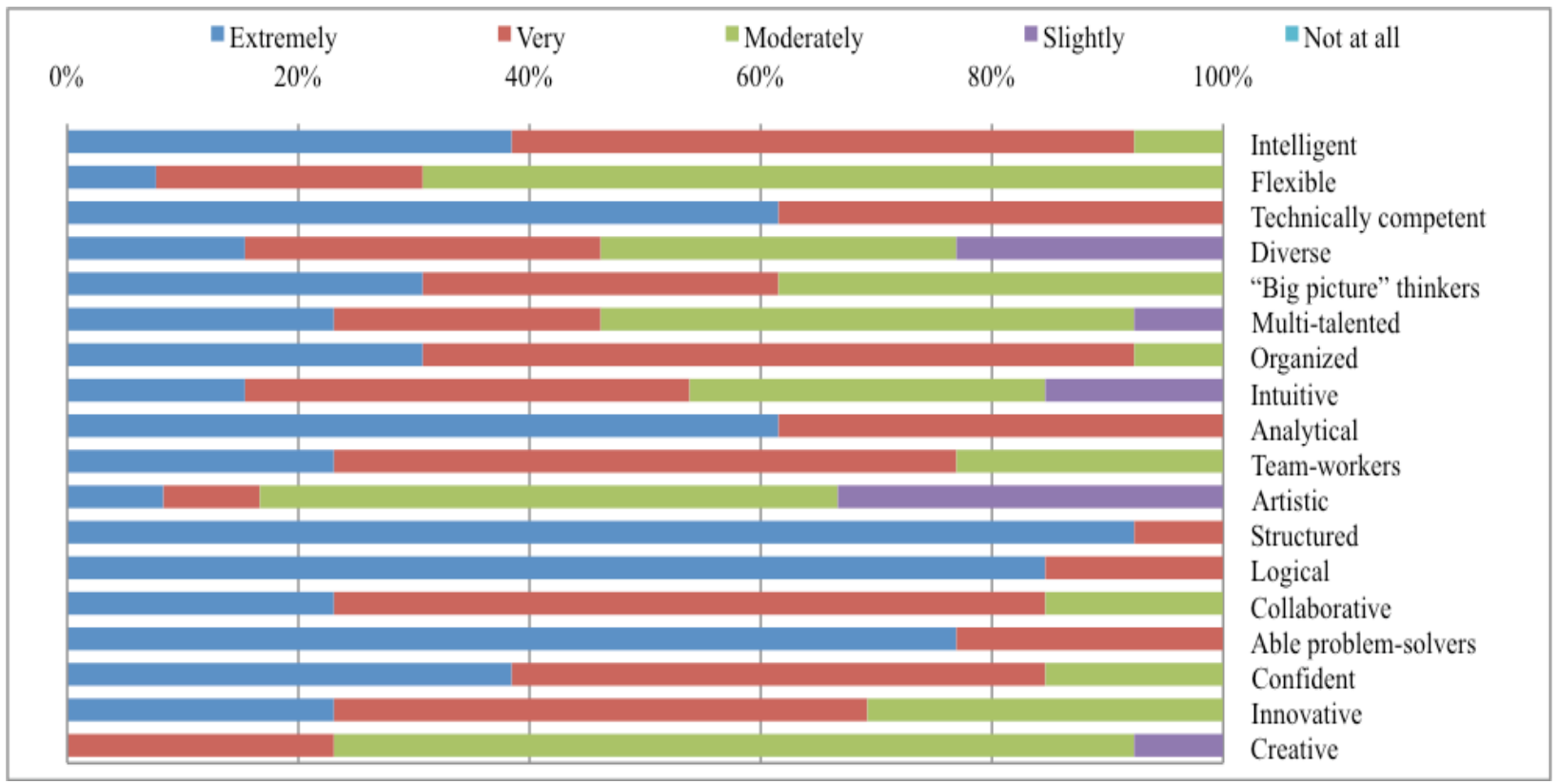

FIGURE 16

Architecture Students on EngineErs Pre-Course

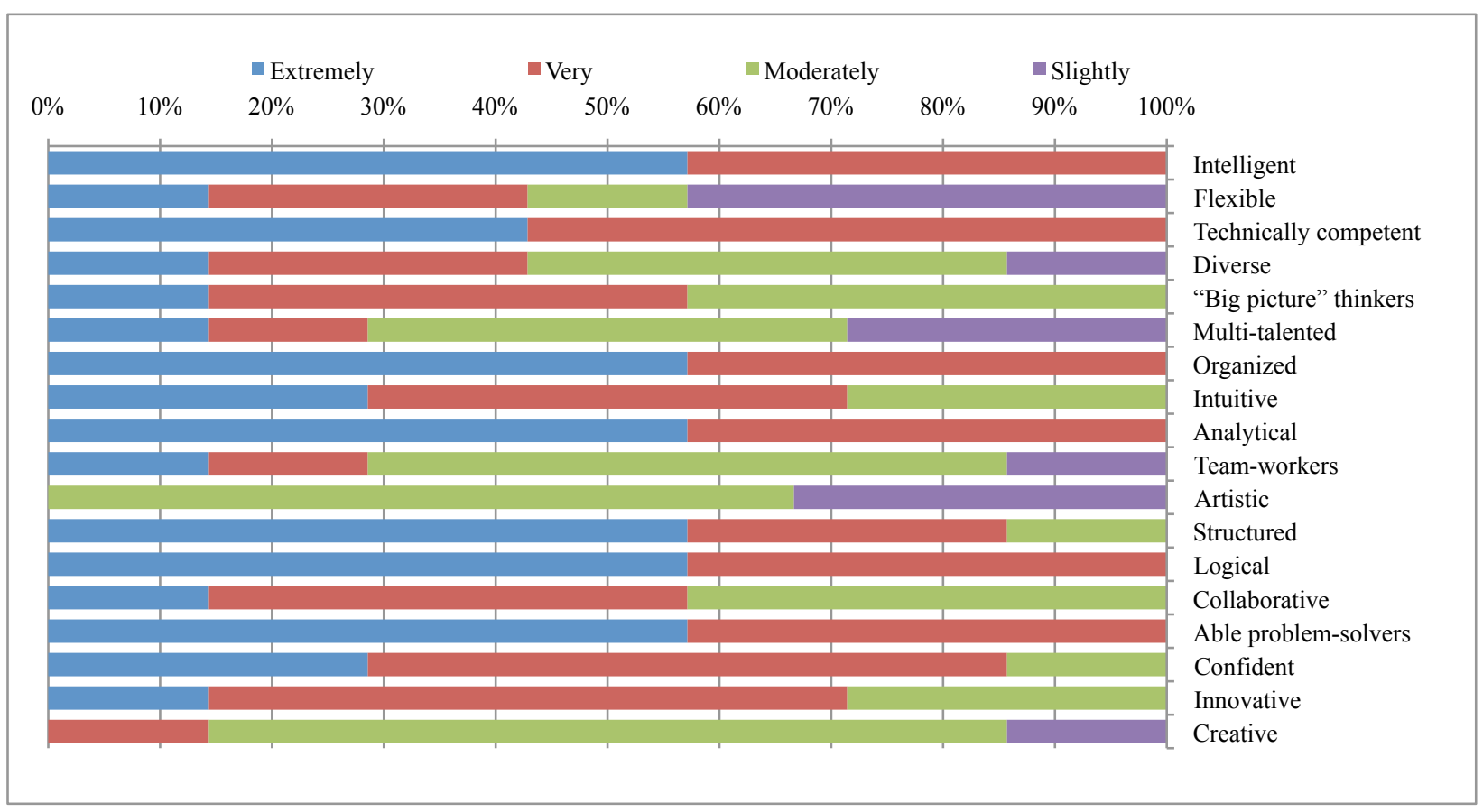

FIGURE 17

Architecture Students on EngineERs Post-Course 


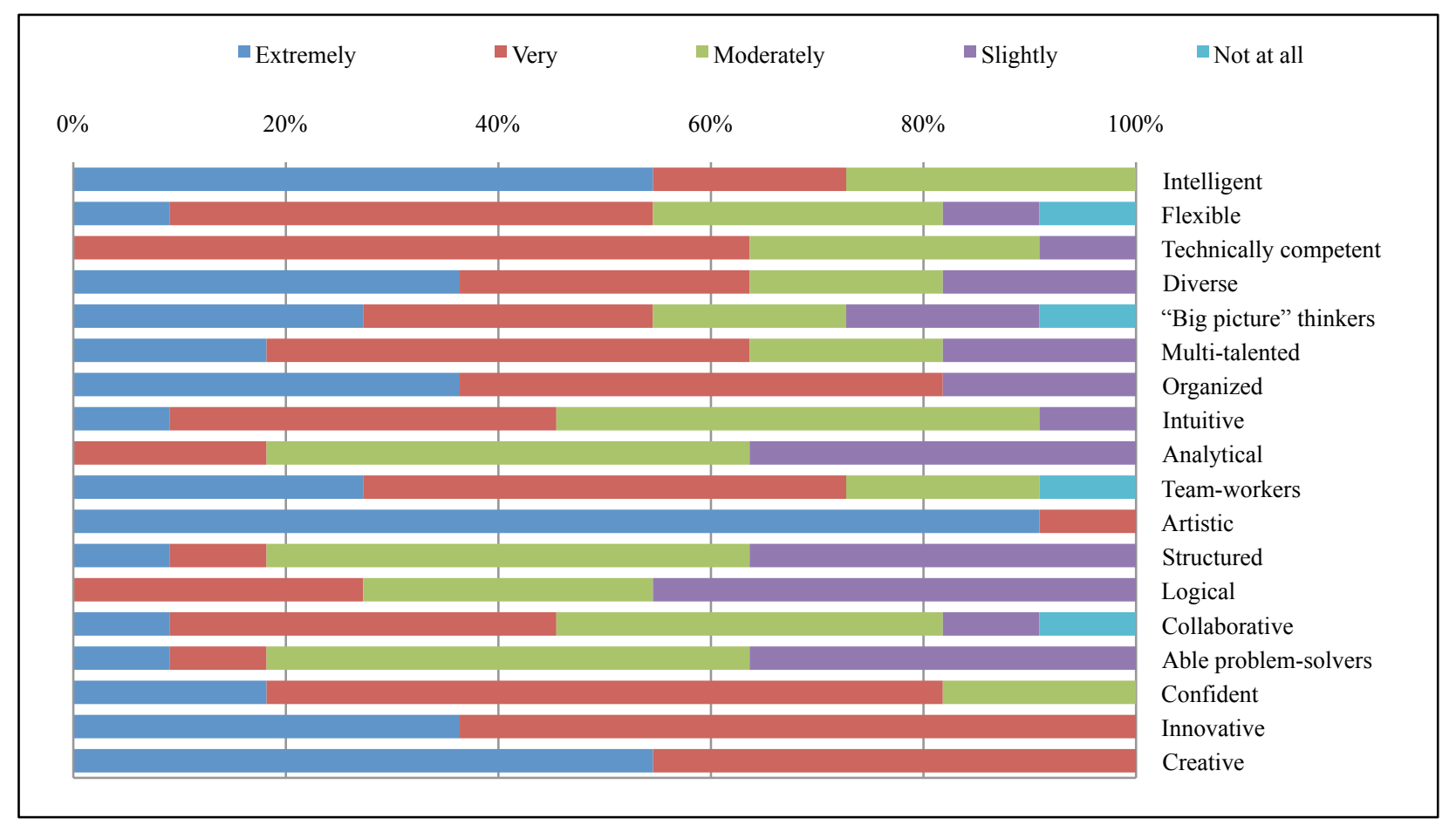

FigURE 18

Engineering Students on Architects Pre-Course

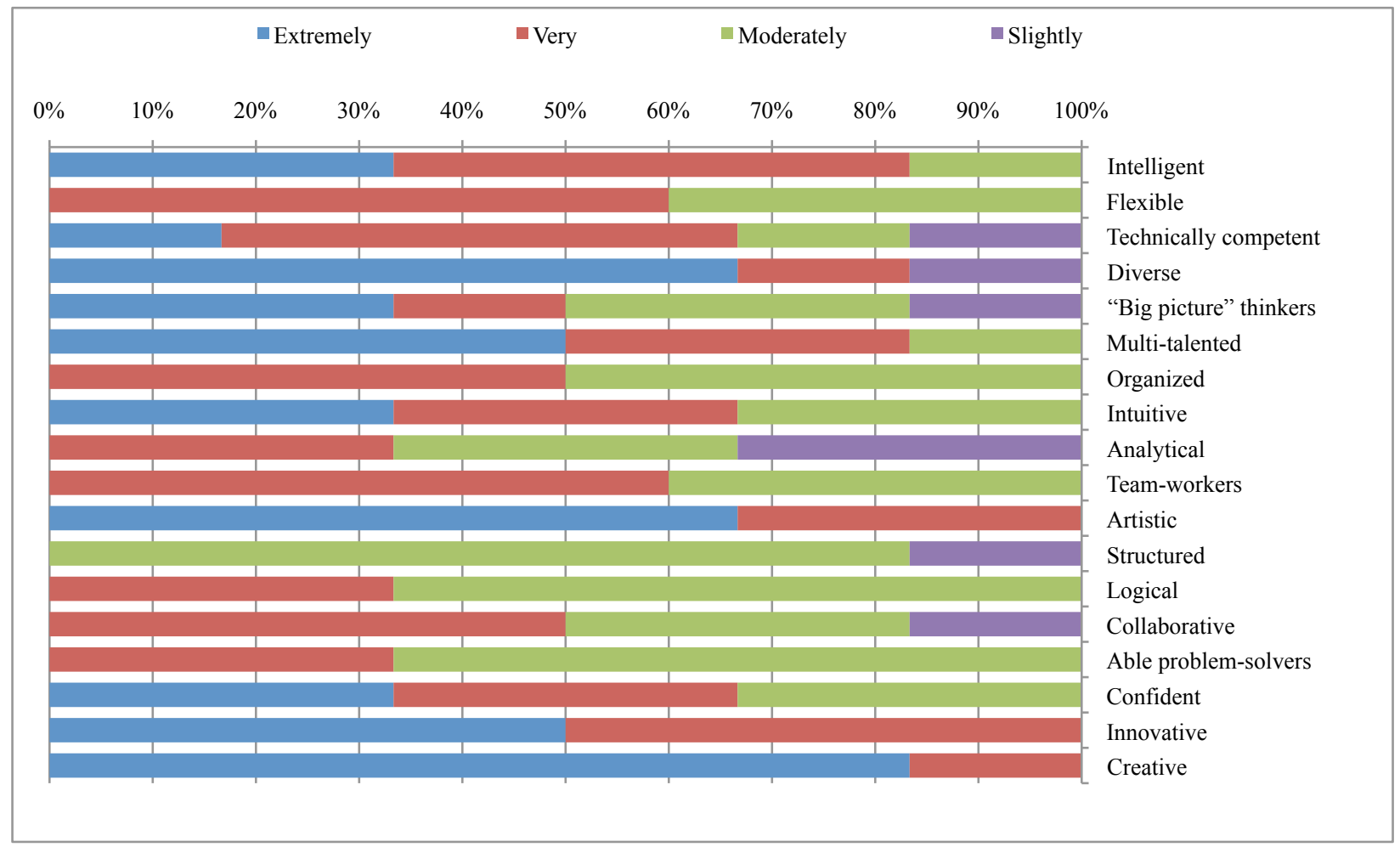

FIGURE 19

Engineering Students on Architects Post-Course 
${ }^{1}$ Katehi, L. 2005. The Global Engineer. Educating the Engineer of 2020: Adapting Engineering Education to the New Century. National Academy of Sciences, 4

${ }^{2}$ Hughes, T. P. 1990. American Genesis: A History of the American Genius for Invention. 1st Ed. New York: Penguin Books, 5.

${ }^{3}$ Vest, C. 2005. Educating Engineers for 2020 and beyond. Educating the Engineer of 2020: Adapting Engineering Education to the New Century. National Academy of Sciences, 163.

${ }^{4}$ Atman, C. J. Adams, R. S. Cardella, M. E. Turns, J. Mosborg, S. Saleem, J. 2007 Engineering Design Processes: A Comparison of Students and Expert Practitioners. Journal of Engineering Education, 96(4) pg. 359

${ }^{5}$ Dally, J. W., and Zhand, G. M. 1994. A Freshman Engineering Design Course. Journal of Engineering Education 83(2) pp 83-9.

${ }^{6}$ Dym, C.L. Agogino, A. M. . Eris, O. Frey, D. D. Leifer, L. J. 2005. Engineering Design Thinking, Teaching, and Learning Journal of Engineering Education. 94(1) pp 103-120

${ }^{7}$ Katehi, Linda and Ross, Michael. 2001. Technology and Culture: Exploring the Creative Instinct through Cultural Interpretations. Journal of Engineering Education. 96(2) pp 89-90

${ }^{8}$ Court, A. W., 1998. Improving creativity in engineering design education. European Journal of Engineering Education, 23(2) pp141-153

${ }^{9}$ Blicblau, Aaron S., and Steiner, Joseph M. 1998. Fostering creativity through engineering projects. European Journal of Engineering Education, 23(1) pp 55-65

${ }^{10}$ Court, A. W., 1998. Improving creativity in engineering design education. European Journal of Engineering Education, 23(2) pp141-153

${ }^{11}$ Katehi, Linda and Ross, Michael. 2001. Technology and Culture: Exploring the Creative Instinct through Cultural Interpretations. Journal of Engineering Education. 96(2) pp 89-90

${ }^{12}$ Acar, B. Serpil, 1998. Releasing creativity in an interdisciplinary systems engineering course. European Journal of Engineering Education, 23(2) pp133-140

${ }^{13}$ Mac Namara, Sinead, Clare Olsen, Laura Steinberg, and Samuel Clemence. 2010 Inspiring Innovation. Proceedings of the American Society for Engineering Education 2010 Annual Conference and Exposition. ASEE: Louisville, KY, ASEE. 2010.

${ }^{14}$ Mac Namara Sinead, Clare Olsen, Scott L. Shablak, and Carolina B. Harris, 2010. Merging Engineering and Architectural Pedagogy - A Trans-disciplinary Opportunity? 2010 ICEE Conference on Engineering Education, Silesian University of Technology, Gliwice, Poland, July 18-22, 2010.

${ }^{15}$ Ibid 